Original article

\title{
Okaliptus balının PC3, CaCO2, HeLa ve HuH7 Kanser Hücre Hatları Üzerindeki Sitotoksisitesinin Değerlendirilmesi
}

Assessment of Eucalyptus Honey-induced cytotoxicity against different cell lines of PC3, CaCO2, HeLa ve HuH7

\author{
Bekir Çöl (1) a, ", Merve Sezer Kürkçü [i] b \& Ali Sorucu (iD c \\ ${ }^{a}$ Department of Biology, Faculty of Science, Muğla Sıtkı Koçman University, Muğla, Turkey \\ ${ }^{\mathrm{b}}$ Biotechnology Research Center, Muğla Sıtkı Koçman University, Muğla, Turkey \\ ' Department of Pharmacology and Toxicology, Faculty of Milas Veterinary Medicine, Muğla Sıtkı Koçman University, Muğla, Turkey
}

\section{Özet}

Prostat, rahim ağzı, kolorektal ve karaciğer kanserlerinin tedavileri sıklıkla yaşam kalitesinin düşmesine neden olan cerrahi ve/veya radyoterapi tedavilerini içermektedir. Kanser tedavisinde kullanılmak için potansiyel doğal antikanser kaynakların araştırılması dünyada devam vermektedir. Bu çalışma, Türkiye’den elde edilen okaliptüs balının farklı konsantrasyonlarının seçilen kanser hücre hatları üzerindeki sitotoksisitesini araştırmayı amaçlamıştır. Bu amaçla, PC3 insan prostat kanseri hücre hattı, HeLa rahim ağzı kanseri hücre hattı, $\mathrm{CaCo} 2$ kolorektal kanseri hücre hattı ve HuH7 karaciğer kanseri hücre hatları kullanılmıştır. Hücre hatlarına 48 ve 72 saat boyunca çeşitli konsantrasyonlarda (\%0.78 - \%50 arası) okaliptüs balı uygulamasını takiben, sitotoksisite tayini için, hücre canlılık testi (MTT) yapılmış ve okaliptüs balının her bir konsantrasyonunda kanser hücrelerinin yüzde canlılık oranları belirlenmiştir. Okaliptus balı uygulaması ile hücre hatlarının canlılıklarını \%80 ve daha fazla kaybettikleri konsantrasyonlara ve bu konsantrasyonlarda hücrelerin canlılık oranlarına bakıldığında, \%6.25 okaliptus balı konsantrasyonunda HeLa hücre hattının 48 ve 72 saatlerinde sırasıyla \%7.6 ve \%7.7, CaCO2 hücre hattının 72 saatinde \%20.7; \%12.5 okaliptus balı konsantrasyonunda HuH7 hücre hattının 48 ve 72 saatlerinde sırasıyla \% 5.3 ve \% 5.1, PC3 hücre hattının 72 saatinde \%5.2, CaCO2 hücre hattının 48 saatinde \%20.4; \%25 okaliptus balı konsantrasyonunda PC3 hücre hattının 48 saatinde \%7.7 canlılık oranları gösterdikleri görülmüştür.

Anahtar Kelimeler: PC3 (prostat kanseri), HeLa (rahim ağzı kanseri), HuH7 (karaciğer kanseri), CaCo2 (kolorektal kanseri), Okaliptüs balı, MTT assay, sitotoksisite.

\begin{abstract}
Treatments for prostate cancer, cervical cancer, colorectal cancer and liver cancer often include surgical and/or radiotherapy treatments that lead to poor quality of life. The studies to find potential natural anticancer sources for use in the treatment of cancer types are actively being pursued in the world. This study aimed to investigate the cytotoxic effects of eucalyptus honey collected from Turkey on selected cancer cell lines. In this study, human prostate cancer cell line PC3, cervical cancer cell line HeLa, colorectal cancer cell line $\mathrm{CaCo} 2$ and liver cancer cell line HuH7 were used. Following the application of eucalyptus honey at various concentrations (0.78\% - 50\%) to the cell lines for 48 and 72 hours, cell viability assay (MTT) was performed to determine the number of viable cells that was indicative of cytotoxicity eucalyptus honey. The concentrations in which the cell lines lose
\end{abstract}

\footnotetext{
* Corresponding author:

Bekir Çöl, Department of Biology, Faculty of Science, Muğla Sıtkı Koçman University, Muğla, Turkey. Email:bcol@mu.edu.tr
} 
their viability by $80 \%$ or more by exposure to eucalyptus honey, and the viability rates of the cells at these concentrations were considered. The results showed that $6.25 \%$ concentration of the eucalyptus honey resulted in $7.6 \%$ and $7.7 \%$ viability at 48 and 72 hours for HeLa cell line, respectively. Moreover, the viability ratios of $20.7 \%$ for $\mathrm{CaCO} 2$ cell line at 72 hours at a concentration of $12.5 \%$ eucalyptus honey; the viability of $5.3 \%$ and $5.1 \%$ at 48 and 72 hours for $\mathrm{HuH} 7$ cell line, the viability of $5.2 \%$ at 72 hours for PC3 cell line, the viability of $20.4 \%$ at 48 hours of $\mathrm{CaCO} 2$ cell line; at $25 \%$ eucalyptus honey concentration and the viability of $7.7 \%$ in 48 hours of PC3 cell line were determined.

Keywords: PC3 (prostate cancer), HeLa (cervical cancer), HuH7 (liver cancer), CaCo2 (colorectal cancer), Eucalyptus Honey, MTT assay, cytotoxicity.

Received: 22 November $2021 \quad * \quad$ Accepted: 29 December $2021 \quad * \quad$ Dol: https://doi.org/10.29329/ijiasr.2021.414.3

\section{GíRiș}

Kanser dünya genelinde önemli bir halk sağlığı sorunu olup, günümüzde çok yaygın olarak görülen hastalıklar arasında yer almaktadır. Gelişmiş ülkelerde her üç kişiden birini etkilediği ve kardiyovasküler hastalıklar ile birlikte ölümlerin önde gelen iki nedeni olarak rapor edilmektedir. Küresel olarak, dünyadaki her 6 ölümden yaklaşık 1'i kanserden kaynaklanmaktadır (Mao ve ark., 2016; WHO, 2018).

Prostat, kolorektal, rahim ağzı ve karaciğer kanserleri dünyada sıklıkla hastalarda görülen ilk 10 kanser arasında yer almaktadır. 2020 yılında Dünya Sağlık Örgütü (WHO) verilerine göre tüm yeni kanser vakalarının \%7.3'ü prostat kanseri, \%3.1'i rahim ağzı kanseri, \%10’u kolorektal kanser ve \%4.7'si karaciğer kanseri olarak raporlanmıştır (International Agency for Research on Cancer., 2018a, International Agency for Research on Cancer., 2018b)

Prostat kanseri, rahim ağzı kanseri, kolorektal kanseri ve karaciğer kanserlerinin tedavileri yaşam kalitesinin düşmesine neden olan cerrahi ve/veya radyoterapi tedavilerini içermektedir. Kanser türlerinin tedavisinde kullanılmak için potansiyel doğal antikanser kaynaklarının araştırılması çalışmalara yön vermektedir.

Bal gibi doğal ürünler potansiyel antikanser etkilere sahiptirler (Othman, 2012). Bal, Apis mellifera arıları tarafından üretilen doğal bir gıda ürünüdür. Bal, sadece besin değeri için değil aynı zamanda iyileştirici özellikleri nedeniyle yüzyıllardır farklı kültürlerde geleneksel ilaç olarak kullanılmaktadır. Arıların nektar aldığı bitki kaynağına göre bal, farklı kimyasal ve sağlıklı etkilere sahip olmaktadır. İçeriklerinde yüksek oranda şeker olmasının yanı sıra balın kalitesine ve insanların sağlıkları için katkıda bulunan proteinler, enzimler, amino asitler, mineraller, vitaminler, organik asitler ve fenolik bileşikler gibi diğer küçük bileşenler de bulunmaktadır (White, 1978; Santos-Buelga ve González-Paramás, 2017). Farklı çiçek kaynakları ve coğrafi bölgelerden elde edilen çeşitli bal türlerinin 
birçok farklı oranda fenolik bileşikler içerdikleri ve tedavilerde farklı düzeylerde etki gösterdikleri görülmüştür (Gomez-Caravaca ve ark., 2006; Simon ve ar., 2009).

Balın antioksidan, antiinflamatuar, antibakteriyel, antimutajenik, antiviral gibi fonksiyonel ve biyolojik aktiviteleri çalışılmış ve çalışılmaktadır (Irish ve ark., 2008; Temaru ve ark., 2007; Boukraa ve ark. 2008; Cooper ve ark., 2001; Sherlock ve ark., 2010; Wang ve ark., 2002; Al-Mamary ve ark., 2002). Antikanser aktiviteleri çeşitli kanser hücre hatları ve dokular ile yapılan çalışmalarda gösterilmiştir (Tomasin ve ark., 2011; Fukuda ve ark., 2011; Tsiapara ve ark., 2009; Fauzi ve ark., 2011; Samarghandian ve ark., 2011). Balın bu aktivitelerinin içerdikleri antioksidan özelliklere sahip flavonoidler gibi fenolik bileşiklere bağlı olduğu düşünülmektedir (Abubakar ve ark., 2012; Jaganathan ve ark., 2009). Bu bileşiklerin bal türleri arasında coğrafi bölgelere, bal arısının besin kaynağına ve iklime bağlı olarak etki yüzdelerinin değiştiği raporlanmıştır (Gheldof ve ark., 2002; Beretta ve ark., 2007; Viuda-Martos ve ark., 2008; Hegazi ve ark., 2009).

Türkiye'de çeşitli ballar üretilmektedir. Okaliptüs balı da bunlardan bir tanesi olup, okaliptüsle beslenen bal arıları tarafından yapılan bir bal türüdür. Okaliptüs balı, üretildiği okaliptus bitkisinden dolayı kendisine atfedilen tıbbi özellikleri nedeniyle dünya çapında ticarileşen ve tüketiciler tarafından çok arzu edilen önemli bir baldır. Genel olarak okaliptüs balı, okaliptüs ağacından elde edilen polen taneleri bakımından zengin olmasının yanı sıra, onu diğer ballardan bir bakıma öne çıkaran fizikokimyasal özelliklere de sahip olduğu gösterilmiştir (Bobis ve ark. 2020).

Coğrafi kökene veya üretim bölgesine göre farklı kimyasal bileşenlere sahip çeşitli okaliptüs balları vardır. Okaliptus balları genellikle besinsel bileşimleri ve kalite parametreleri açısından incelenmiş, potansiyel yararlı etkilerine odaklanan çok az araştırma yapılmıştır (Karabagias ve ark., 2018; Bobis ve ark., 2020). Okaliptüs balının önemli bir antioksidan aktiviteye sahip olmas1 ve mikroorganizmalara karşı antimikrobiyal etki gösterebilmesi bunlar arasındadır. Okaliptüs balının antibakteriyel kapasitesi, farklı coğrafi bölgelerden alınan örneklerde yapılan çalışmalar ile rapor edilmiştir (Coniglio ve ark., 2018; Roshan ve ark., 2017; Valdes ve ark., 2018; Aumeeruddyetal ve ark., 2019).

Bu çalışma, okaliptüs balının farklı konsantrasyonlarının seçilen kanser hücre hatları üzerindeki sitotoksisitesini araştırmayı amaçlamıştır. Bu çalışmada PC3, HeLa, Caco2 ve HuH7 kanser hücre hatları ve Okaliptus balı kullanılmıştır. HeLa, rahim ağzı kanserinden köken alan bir kanser hücresidir ve geliştirilen ilk kanser hücre dizisidir (Masters, 2002). Caco2, kolorektal kanserden gelen bir kanser hücresidir. Çeşitli doğal ürünlerin bu kanser hücre dizilerinin çoğalmasını engellediği gösterilmiştir (Kuppusamy ve ark., 2014). PC3 hücre hattı 1979'da 62 yaşında bir prostat kanser hastasının IV. derece kemik metastazından elde edilmiştir (Kaighn ve ark. 1979). Huh7, 1982'de 57 yaşındaki bir Japon erkek hastanın karaciğer tümöründen alınan, iyi farklılaşmış hepatosit türevli bir karsinom hücre hattıdır (http://huh7.com/). 


\section{MALZEMELER ve YÖNTEMLER}

\section{Malzemeler}

Deneylerde kullanılan kimyasallardan, fetal bovine serum (FBS), trypsin-EDTA, penicillinstreptomycin, Dulbecco's minimum essential medium (DMEM), RPMI-1640 medium, Dulbecco's phosphate buffered saline (dPBS), 3-(4, 5-Dimethylthiazol-2-yl)-2, 5-diphenyl (MTT) M2128, Sigma Aldrich'den temin edilmiştir.

\section{Okaliptus Balı}

Okaliptus balı uygun bitki çiçeklenme mevsiminde doğrudan peteklerden toplanmıştır. Bal örneği mum ve diğer kirliliklerden arındırılarak analiz için hazır hale getirilmiştir. Okaliptus balı RPMI-1640 ve DMEM besiyerleri ile seyreltilerek \%0 ile \%50 (0, 0.83, 1.65, 3.12, 6.25, 12.5, 25 ve \%50) konsantrasyon aralığında hazırlanmıştır. Besiyerleri içerisinde hazırlanan bal çözeltileri $0.22 \square \mathrm{m}$ porlu filtrelerden geçirilerek kullanıma hazır hale getirilmiştir.

\section{Okaliptus Balı Polen analizi}

Polen analizi için Uluslararası Arı Botaniği Komisyonu tarafından önerilen yöntem optimize edilerek kullanılmıştır (Louveaux ve ark., 1978). Baldan 10 gr alınarak $20 \mathrm{ml}$ suda tamamen homojen olana kadar çözülmüştür. Çözelti 2800 g'de 30 dk boyunca santrifüjlenmiştir. Süpernatant döküldükten sonra, pelletin süpernatanttan tamamen arındırılabilmesi için tüp ters çevrilerek 1,5-2 saat bekletilmiştir. Pellet kuruduktan sonra \%25'lik gliserol çözeltisi damlatılarak tamamen çözülene kadar vortekslenmiştir.

Bal örneklerinin polen içeriğini analiz etmek için örnek lam ve lamel arasında hazırlanarak Nikon Ts2-FL mikroskobu altında fotoğraflanmıştır. Polen türleri, palinolojik literatür ve monograflar referans kullanılarak tanımlanmıştır. Polen türlerinin yüzde sıklığı hesaplanmıştır. Polen türleri, (i) baskın polen türleri (sayllan toplam polen tanelerinin \%45'i); (ii) ikincil polen türleri (\%16-45); (iv) minör polen türleri (\%3) olarak gruplandırılmıştır.

\section{Hücre Hatları}

Bu çalışmada dört farklı hücre hattı kullanılmıştır. PC3 ATCC (CRL-1435) insan prostat kanseri hücre hattı, HeLa ATCC (CRM-CCL-2) rahim ağzı kanseri hücre hatt1, CaCo2 ATCC (HTB-37) kolorektal kanseri hücre hatları ATCC hücre hatları olup diğer hücre hattı HuH7 karaciğer kanseri hücre hattıdir ((http://huh7.com/).

\section{Hücre Kültürï̈}

İnsan prostat kanseri hücre dizisi (PC3) ve karaciğer kanser hücre hattı (HuH7) 10\% fetal bovine serum, $\% 1$ glutamin, $\% 1$ penisilin ve $\% 1$ streptomisin ile desteklenmiş RPMI-1640 besiyerinde, rahim 
ağzı kanseri hücre hattı (HeLa) ve kolorektal kanser hücre hattı (CaCo2) 10\% fetal bovine serum, \%1 glutamin, \%1 penisilin ve \%1 streptomisin ile desteklenmiş DMEM besiyerlerine ekimleri yapılarak $37^{\circ} \mathrm{C}$ de, $\% 5 \mathrm{CO}_{2}{ }^{\prime} l i$ ve $\% 99$ nemlendirilmiş inkübatörde inkübasyona bırakılmıştır. Hücrelerin besiyeri haftada 3 defa olacak şekilde değiştirilmiştir ve \%80-90 konfluent olduklarında hücreler kaldırılarak MTT ölçümünün yapılacağı 96 kuyucuklu platelere alınmıştır. 96 kuyucuklu platelerde her kuyucukta PC3, HuH7 ve CaCo2 hücre hatları için $4 \times 10^{4}$, HeLa hücre hattı için $3 \times 10^{4}$ hücre ekimleri gerçekleştirilmiştir. Hücreler, 24 saat boyunca 96 kuyucuklu doku kültürü plakalarında kültürlenmiştir.

Kültür ortamı daha sonra aspire edilerek RPMI-1640 ve DMEM içinde farklı bal konsantrasyonlarında hazırlanan besiyerleri ilave edilmiştir. Plateler, 48 ve 72 saat boyunca nemlendirilmiş havada $\% 5 \mathrm{CO} 2$ içinde $37^{\circ} \mathrm{C}$ 'de inkübe edilmiş ve ardından faz kontrast mikroskobu ile incelenmiştir.

\section{MTT assay ile sitotoksisitenin belirlenmesi}

Tetrazolyum tuzu 3-(4,5-dimetiltiazol-2-il)-2,5-difeniltetrazolyum bromürün (MTT) mavi bir formazan kristaline indirgenmesi, mitokondriyal dehidrojenaz ve NADPH'ye bağlı hücresel oksidoredüktaz enzimleri tarafindan gerçekleştirilmektedir (Berridge \& Tan, 1993; Mosmann, 1983). 96 kuyucuklu doku kültürü plakalarında çeşitli bal (\%0-\%50 aralığında) dilüsyonlarında PC3, HeLa, $\mathrm{CaCO} 2, \mathrm{HuH} 7$ hücrelerinin 48 ve 72 saat inkübasyonlarından sonra, besiyerleri aspire edilerek her bir kuyucuğa $0.5 \mathrm{mg} / \mathrm{ml}$ MTT konsantrasyonunda besiyeri ilave edilerek 3 saat süreyle $37^{\circ} \mathrm{C}$ de inkübe edilmiştir. Metabolik olarak aktif hücreler, MTT'yi mavi formazan kristallerine indirgemiştir. MTT içeren besiyeri aspire edilerek her kuyucuğa $100 \mu \mathrm{L}$ DMSO (\%100) ilave edilerek mavi formazan kristallerinin çözülmesi sağlanmıştır. Absorbanslar mikroplate'de 570 nm'de ölçülmüştür. Hücre canlılığı bal içermeyen besiyerinde büyüyen hücrelerin yüzdesi olarak hesaplanarak grafikler oluşturulmuştur.

\section{BULGULAR}

\section{Okaliptus Balının Polen analizi}

Çalışmamızda kullanılmış olan Okaliptus balında 5 familyaya ait polen çeşitlerine rastlanmıştır. Bunlardan \%45 oranında Eucalyptus camaldulensis Dehn. bitkisine ait polen türü baskın polen türü olarak görülmüştür. Vitex agnus castus L. türüne ait polen türü \%30 oranında ikincil polen türü olarak görülmüştür. Asteraceae (\%3), Fabaceae $(\% 1)$, Apiaceae $(\% 1)$ familyalarına ait polen türleri minör polen türleri olarak görülmüştür (Şekil 1). 


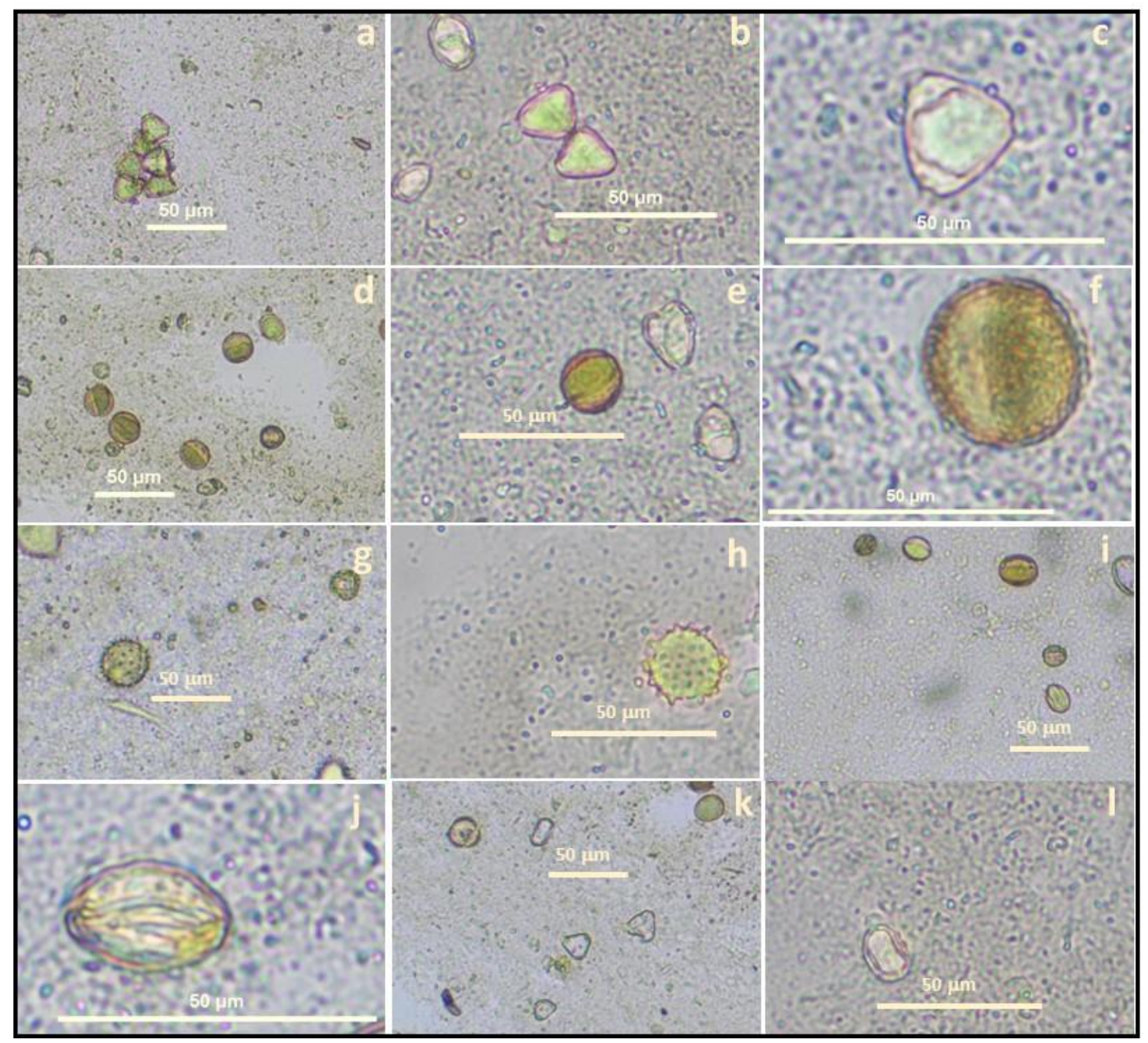

Şekil 1. Okaliptus bal örneğinden elde edilen, seçilen polen tanelerinin fotomikrografları. a-c Eucalyptus camaldulensis Dehn.; d-f Vitex agnus castus L.; g-h Asteraceae; i-j Fabaceae; k-l Apiaceae.

\section{Okaliptus balının sitotoksisite analizi}

Artan okaliptus bal konsantrasyonlarında $\mathrm{PC} 3, \mathrm{HeLa}, \mathrm{HuH} 7$ ve $\mathrm{CaCO} 2$ hücre hatlarında, hücre canl111klarında belirgin azalmalar görülmüştür (Şekil 1-4.)

PC3 hücre hattının 48 saat boyunca Okaliptus balına maruz bırakılması ile \%25 okaliptus balı konsantrasyonunda hücre canlılığ $\% 7.7,72$ saat boyunca okaliptus balına maruz bırakılması ile \%12,5 okaliptus balı konsantrasyonunda hücre canlılı̆̆ $\% 5,2$ olarak görülmüştür (Şekil 2). 
PC3

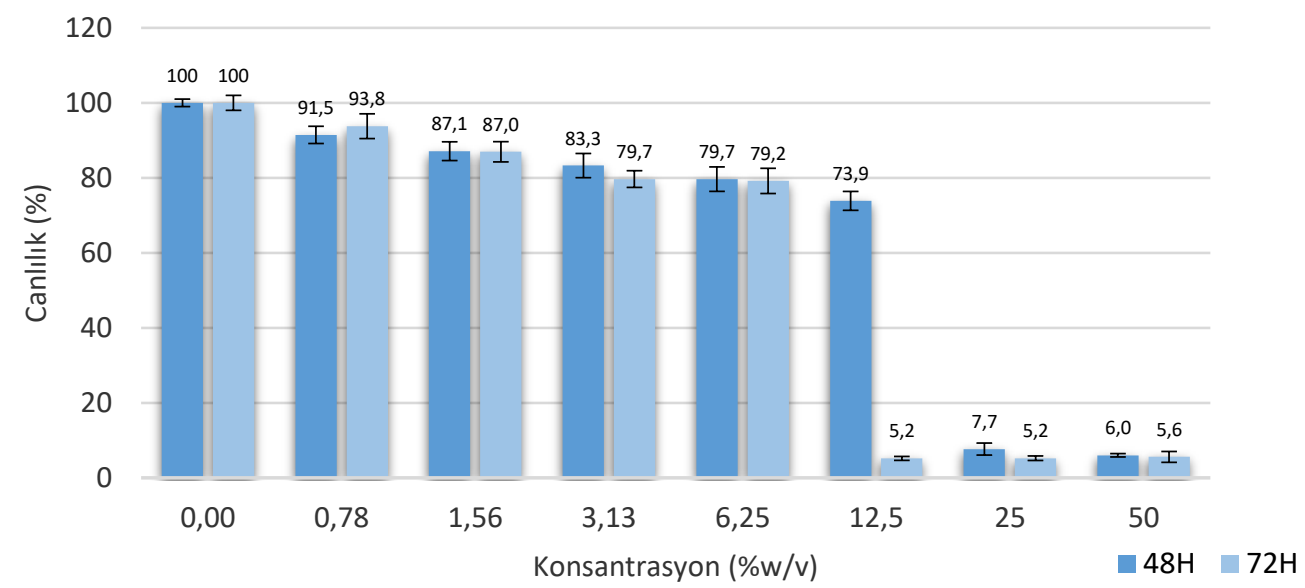

Şekil 2. PC3 hücrelerine 48 saat ve 72 saat okaliptüs balı uygulanması sonrası saptanan canl111k oranları $(\%)$.

HeLa hücre hattının 48 saat boyunca okaliptus balına maruz bırakılması ile \%6.25 okaliptus balı konsantrasyonunda hücre canlılığ $\% 7.6,72$ saat boyunca okaliptus balına maruz bırakılması ile \%6.25 okaliptus balı konsantrasyonunda hücre canlılığı \% 7.7 olarak görülmüştür (Şekil 3).

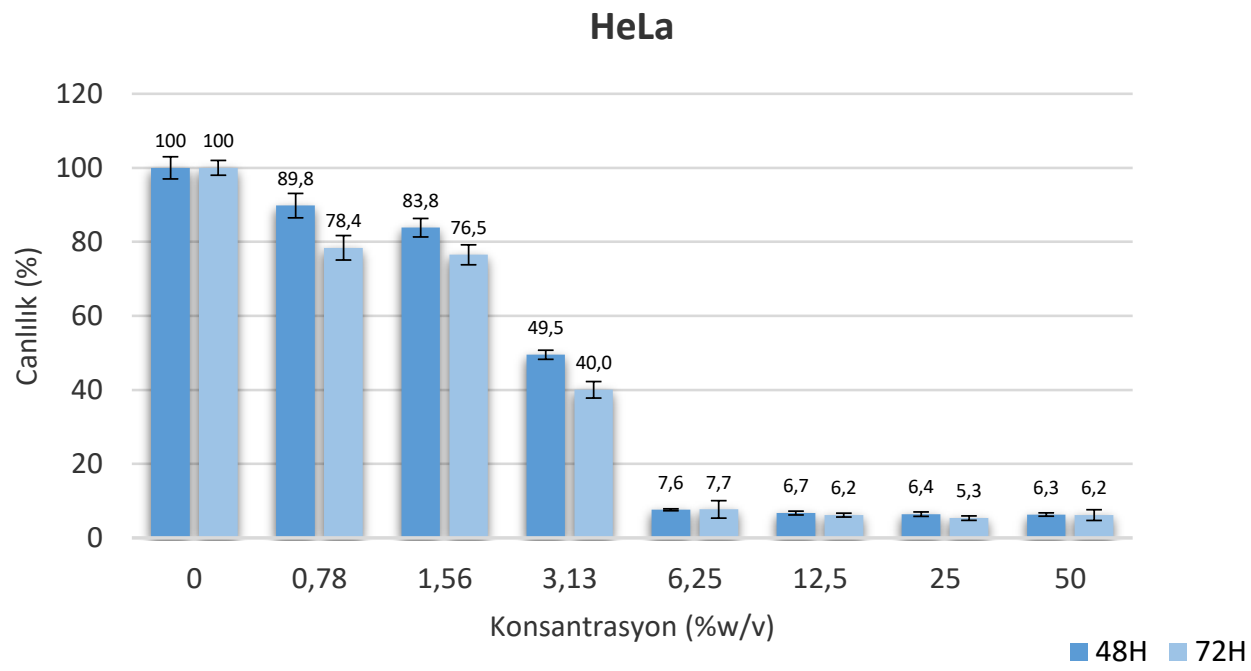

Şekil 3. HeLa hücrelerine 48 saat ve 72 saat okaliptüs balı uygulanması sonrası saptanan canl1l1k oranları (\%).

HuH7 hücre hattının 48 saat boyunca okaliptus balına maruz bırakılması ile \%12.5 okaliptus balı konsantrasyonunda hücre canlılığ $\% 5.3,72$ saat boyunca okaliptus balına maruz birakılması ile $\% 12.5$ okaliptus balı konsantrasyonunda hücre canlılığı \%5.1 olarak görülmüştür (Şekil 4). 


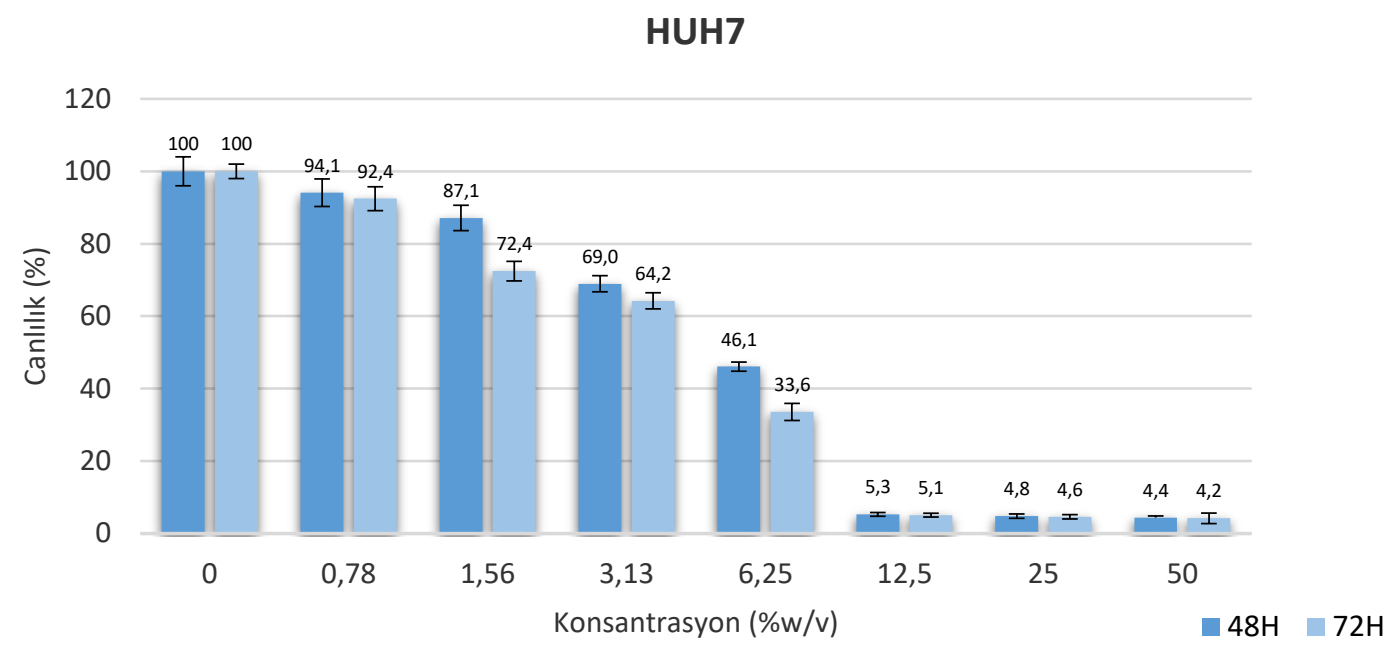

Şekil 4. HuH7 hücrelerine 48 saat ve 72 saat okaliptüs balı uygulanması sonrası saptanan canlılık oranları $(\%)$.

$\mathrm{CaCO} 2$ hücre hattının 48 saat boyunca okaliptus balına maruz bırakılması ile \%12.5 okaliptus balı konsantrasyonunda hücre canlılı̆̆ $\% 20.4,72$ saat boyunca okaliptus balına maruz birakılması ile \%6.25 okaliptus balı konsantrasyonunda hücre canlılığı \%20.7 olarak görülmüş̧ür (Şekil 5).

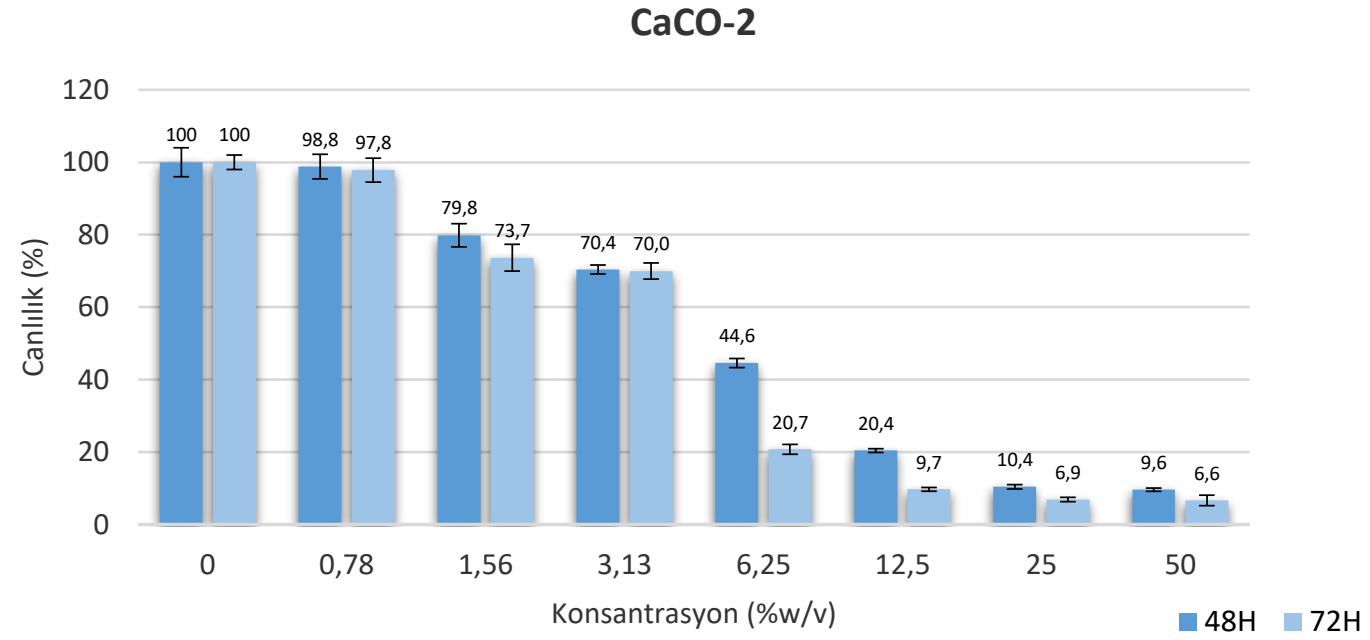

Şekil 5. CaCo2 hücrelerine 48 saat ve 72 saat okaliptüs balı uygulanması sonrası saptanan canlılık oranları $(\%)$.

\section{SONUÇ}

Kanser hastanın yaşam kalitesini önemli ölçüde etkilemektedir. Kansere karşı standart tedaviler, cerrahi müdahaleler, radyoterapi ve/veya kemoterapidir. Bu tedavilerin ciddi yan etkileri bulunmaktadır (Chari, 2008). Bir tedavi yöntemine karar verilirken ilacın sadece yaşam süresine katkısı değil, bu süreç içerisinde yaşam kalitesine de olumlu katkısı göz önünde bulundurulmalıdır. Kanser tedavisi için yeni 
hedefler, karsinogenezde ihtiyaç duyulan spesifik moleküllere müdahale etmeye odaklanmaktadır (Goldman, 2003). Bunun için yeni doğal antikanser ilaçlarını bulmaya yönelik yapılan araştırmalar, bilimsel araştırmalarda önemli bir yere sahiptir.

$\mathrm{Bu}$ çalışmada Muğla çevresinden elde edilen Okaliptus balının PC3, HeLa, HuH7 ve CaCO2 kanser hücre hatlarında sitotoksik etki gösterdiği görülmüştür. MTT test sonuçları değerlendirildiğinde okaliptus balının farklı konsantrasyonlarının çalışılan hücre hatlarında \%80'den fazla sitotoksisiteyi sağladığı görülmüştür. Bu hücre hatlarından rahim ağZı kanser hücrelerinin (HeLa) \%6.25 okaliptus balı konsantrasyonunda hem 48 hem de 72 saat maruz bırakıldığı saatlerde canlılıklarını \%90'dan daha fazla kaybettikleri görülmüştür. $\mathrm{Bu}$ oranlar diğer hücre hatları için $\% 12.5$ ve $\% 25$ okaliptus konsantrasyonlarında görülmüştür (Çizelge 1).

Tablo 1. Hücre hatlarının okaliptüs balının farklı konsantrasyonlarında \% canlılık oranları

\begin{tabular}{lcccc}
\hline Hücre Hattı/Okaliptus Balı Konsantrasyonu & $\mathbf{\% 6 . 2 5}$ & $\mathbf{\% 1 2 . 5}$ & $\mathbf{\% 2 5}$ & Süre \\
\hline \multirow{2}{*}{ PC3 } & 79,70 & 73,90 & 7,70 & 48 saat \\
\hline HeLa & 79,20 & 5,20 & 5,20 & 72 saat \\
\hline \multirow{2}{*}{ HuH7 } & 7,60 & 6,70 & 6,40 & 48 saat \\
& 7,70 & 6,20 & 5,30 & 72 saat \\
\hline \multirow{2}{*}{ CaCO2 } & 46,10 & 5,30 & 4,80 & 48 saat \\
& 33,60 & 5,10 & 4,60 & 72 saat \\
\hline
\end{tabular}

$\mathrm{Bu}$ çalışmada görülmektedir ki Okaliptus balı farklı konsantrasyonları prostat kanser hücreleri, rahim ağzı kanser hücreleri, karaciğer kanser hücreleri ve kolon kanseri hücreleri üzerinde sitotoksik etkiye sahiptir.

Balın çeşitli mekanizmalar yoluyla antikanser ajan olma potansiyeline sahip olabileceğine dair sonuçlar artmaktadır. Kanser hücresini nasıl etkilediğine dair mekanizmalar tam anlaşılamamış olsa da antimutajenik, anti-inflamatuar etkileri ve apoptozu indüklemesi ile antikanser etki gösterdiği literatürde görülmektedir. Farklı bitki kaynaklarından meydana gelen balların farklı etkiler gösterdikleri görülmektedir. Bal ve kanser arasındaki ilişkinin anlaşılması için daha fazla araştırmaya ihtiyaç duyulmaktadır.

\section{Teşekkür}

Desteklerinden dolayı TÜBİTAK ve MSKÜ-BAP birimine teşekkür ederiz. 


\section{KAYNAKÇA}

Abubakar M. B., Abdullah W. Z., Sulaiman S. A., and Suen A. B., 2012 "A review of molecular mechanisms of the anti-leukemic effects of phenolic compounds in honey," International Journal of Molecular Sciences, vol. 13, no. 11, pp. 15054-15073.

Al-Mamary M., Al-Meeri A., and Al-Habori M., 2002 "Antioxidant activities and total phenolics of different types of honey," Nutrition Research, vol. 22, no. 9, pp. 1041-1047.

Aumeeruddy M.Z., Aumeeruddy-Elalfi, Z., Neetoo H., Zengin G., BlomvanStaden A., Fibrich B., etal. (2019). Pharmacological activities, chemical profile, and physicochemical properties of rawand commercial honey. Biocatalysis and Agricultural Biotechnology,18,101005.

Goldman B., (2003) "Combinations of targeted therapies take aim at multiple pathways" Journal of the National Cancer Institute, vol. 95, no. 22, pp. 1656-1657,

Beretta G, Orioli M, Facino RM. Antioxidant and radical scavenging activity of honey in endothelial cell cultures (EA.hy926) Planta Med. 2007;73(11):1182-1189. doi: 10.1055/s-2007-981598.

Berridge MV, Tan AS. Characterization of the cellular reduction of 3-(4,5-dimethylthiazol-2-yl)-2,5diphenyltetrazolium bromide (MTT): subcellular localization, substrate dependence, and involvement of mitochondrial electron transport in MTT reduction. Arch Biochem Biophys. 1993 Jun;303(2):47482.

Bobis, O.; Moise, A.R.; Ballesteros, I.; Reyes, E.S.; Durán, S.S.; Sánchez-Sánchez, J.; Quintanai, S.C.; Giampieri, F.; Battino, M.; Alvarez-Suarez, J.M. Eucalyptus honey: Quality parameters, chemical composition and health-promoting properties. Food Chem. 2020, 325, 126870.

Boukraa L, Amara K. Synergistic effect of starch on the antibacterial activity of honey. J Med Food. 2008;11(1):195-198.

Chari R. V. J., (2008) "Targeted cancer therapy: conferring specificity to cytotoxic drugs" Accounts of Chemical Research, vol. 41, no. 1, pp. 98-107.

Coniglio M.A., Laganà P., Faro G., \& Marranzano M. (2018). “Antimicrobial potential of Sicilian honeys against Staphylococcus aureus and Pseudomonas aeruginosa” Journal of AOAC International, 101(4), 956-959.

Cooper R. A., Molan P., Krishnamoorthy L., and Harding K., "Manuka honey used to heal a recalcitrant surgical wound," European Journal of Clinical Microbiology and Infectious Dis- eases, vol. 20, no. 10, pp. 758-759, 2001.

Fauzi A. N., Norazmi M. N., and Yaacob N. S., 2011 "Tualang honey induces apoptosis and disrupts the mitochondrial membrane potential of human breast and cervical cancer cell lines," Food and Chemical Toxicology, vol. 49, no. 4, pp. 871-878,

Fukuda M., Kobayashi K., Hirono Y. et al., 2011 "Jungle honey enhances immune function and antitumor activity," Evidence- Based Complementary and Alternative Medicine, vol. 2011, Article ID 908743, 8 pages,.

Gheldof N., Wang X. H., and Engeseth N. J., 2002 "Identification and quantification of antioxidant components of honeys from various floral sources," Journal of Agricultural and Food Chemistry, vol. 50, no. 21, pp. 5870-5877. 
Gomez-Caravaca AM, Gomez-Romero M, Arraez-Roman D, Segura-Carretero A, Fernandez-Gutierrez A. Advances in the analysis of phenolic compounds in products derived from bees. J Pharm Biomed Anal. 2006;41(4):1220-1234.

Greenlee RT, Murray T, Bolden S, Wingo PA. Cancer statistics, 2000. CA Cancer J Clin 2000; 50: 7-33.

Hegazi AG, Abd El-Hady FK. Influence of Honey on the Suppression of Human Low Density Lipoprotein (LDL) Peroxidation (In vitro) Evid Based Complement Alternat Med. 2009;6(1):113-121. doi: 10.1093/ecam/nem071.

http://huh7.com/

International Agency for Research on Cancer. 2018a. Cancer Fact Sheets. World Health Organization. https://gco.iarc.fr/today/fact-sheets-cancers

International Agency for Research on Cancer. 2018b. Indonesia Global Cancer Observatory. World Health Organization. https://gco.iarc.fr/today/data/factsheets/populations/360-indonesia-fact-sheets.pdf

Irish J, Carter DA, Blair SE, Heard TA. 2008 "Antibacterial activity of honey from the Australian stingless bee Trigona carbonaria.” Int J Antimicrob Agents.;32(1):89-90.

Jaganathan S. K. and Mandal M., 2009 "Antiproliferative effects of honey and of its polyphenols: a review," Journal of Biomedicine and Biotechnology, vol. 2009, Article ID 830616, 13 pages,.

Kaighn ME, Narayan KS, Ohnuki Y, Lechner JF, Jones LW (1979). "Establishment and characterization of a human prostatic carcinoma cell line (PC3)". Investigative Urology. 17 (1): 16-23.

Karabagias I.K., Maia M., Karabagias V.K., Gatzias I., Badeka A.V. (2018) "Characterization of Eucalyptus, Chestnut and Heather Honeys from Portugal Using Multi-Parameter Analysis and Chemo-Calculus" Foods, 7 (12), p. 194.

Kuppusamy P., Yusoff M.M., Maniam G.P., Ichwan S.J.A., Soundharrajan I., Govindan N. (2014) "Nutraceuticals as potential therapeutic agents for colon cancer: a review" Acta Pharm. Sin. B, 4 (3), pp. 173-181

Mao, Y.; Yang, D.; He, J.; Krasna, M.J. (2016) "Epidemiology of Lung Cancer. Surg. Oncol. Clin. N. Am., $25,439-445$

Masters J.R. (2002) "HeLa cells 50 years on: the good, the bad and the ugly" Nat. Rev. Cancer, 2 (4), pp. $315-319$

Mosmann T. 1983 "Rapid colorimetric assay for cellular growth and survival: application to proliferation and cytotoxicity assays." J Immunol Methods. Dec 16;65(1-2):55-63.

Othman N. H., 2012. "Honey and cancer: sustainable inverse relationship particularly for developing nations-a review," Evidence- Based Complementary and Alternative Medicine, vol. 2012, Article ID 410406, 10 pages.

Roshan N., Rippers T., Locher C., Hammer K.A. (2017). Antibacterial activity and chemical characteristics of several Western Australian honeys compared to manuka honey and pasture honey. Archives of Microbiology, 199(2), 347-355.

Sağlık Bakanlığı Kanserle Savaş Dairesi Başkanlı̆̆ı. "2005 Y1lı Türkiye Kanser İstatistikleri” www.saglik.gov.tr/TR/dosya/1-44481/h/kanseristatistikleri.xls 18.02.2011. 
Samarghandian S., Afshari J. T., and Davoodi S., 2011 "Honey induces apoptosis in renal cell carcinoma," Pharmacognosy Magazine, vol. 7, no. 25, pp. 46-52.

Santos-Buelga, C., \& González-Paramás, A. M. (2017). Chemical composition of honey. In Bee Products Chemical and Biological Properties (pp. 43-82).

Sherlock O., Dolan A., Athman R. et al., 2010 "Comparison of the antimicrobial activity of Ulmo honey from Chile and Manuka honey against methicillin-resistant Staphylococcus aureus, Escherichia coli and Pseudomonas aeruginosa," BMC Complementary and Alternative Medicine, vol. 10, article 47.

Simon A, Traynor K, Santos K, Blaser G, Bode U, Molan P. 2009 Medical honey for wound care--still the 'latest resort'? Evid Based Complement Alternat Med.;6(2):165-173.

Temaru E, Shimura S, Amano K, Karasawa T. 2007 Antibacterial activity of honey from stingless honeybees (Hymenoptera; Apidae; Meliponinae) Pol J Microbiol.;56(4):281-285.

Tomasin R. and Cintra Gomes-Marcondes M.C., 2011 "Oral administration of Aloe vera and honey reduces walker tumour growth by decreasing cell proliferation and increasing apoptosis in tumour tissue," Phytotherapy Research, vol. 25, no. 4, pp. 619-623.

Tsiapara A. V., Jaakkola Chinou M., I. et al., 2009 "Bioactivity of Greek honey extracts on breast cancer (MCF-7), prostate cancer (PC3) and endometrial cancer (Ishikawa) cells: profile analysis of extracts," Food Chemistry, vol. 116, no. 3, pp. 702-708,.

Valdes-Silverio L. A., Iturralde G., García-Tenesaca M., Paredes-Moreta J., Narváez-Narváez D.A., RojasCarrillo M., etal. (2018). Physicochemical parameters, chemical composition, antioxidant capacity, microbial contamination and antimicrobial activity of Eucalyptus honey from the Andean region of Ecuador. Journal of Apicultural Research,57(3),382-394.

Vineis P, Wild CP. (2014) “Global cancer patterns: causes and prevention.” Lancet.;383(9916):549-557.

Viuda-Martos M, Ruiz-Navajas Y, Fernandez-Lopez J, Perez-Alvarez JA. 2008 Functional properties of honey, propolis, and royal jelly. J Food Sci.;73(9):R117-124.

Wang X, Yuan S, Wang J, Lin P, Liu G, Lu Y, Zhang J, Wang W, Wei Y. 2006 “Anticancer activity of litchi fruit pericarp extract against human breast cancer in vitro and in vivo." Toxicol Appl Pharmacol. ;215(2):168-178.

Wang X. H., Andrae L., and Engeseth N. J., 2002 "Antimutagenic effect of various honeys and sugars against Trp-p-1,” Journal of Agricultural and Food Chemistry, vol. 50, no. 23, pp. 6923-6928.

White J. W., 1978 "Honey” Advances in Food Research, Academic Press, Vol 24, Pages 287-374, ISSN 0065-2628.

World Health Organization, 2018. Cancer: Key Facts. https://www.who.int/news-room/factsheets/detail/cancer 